\title{
CHALLENGING THE COLD: CRABS RECONQUER THE ANTARCTIC
}

\author{
Sven Thatje, ${ }^{1,5}$ Klaus Anger, ${ }^{2}$ Javier A. Calcagno,${ }^{3}$ Gustavo A. Lovrich,${ }^{4}$ Hans-Otto Pörtner, \\ AND Wolf E. ARntz ${ }^{1}$ \\ ${ }^{1}$ Alfred Wegener Institute for Polar and Marine Research, Columbusstr. D-27568 Bremerhaven, Germany \\ ${ }^{2}$ Biologische Anstalt Helgoland, Foundation Alfred Wegener Institute, Helgoland, Germany \\ ${ }^{3}$ Universidad de Buenos Aires, Facultad de Ciencias Exactas y Naturales, Intendente Güiraldes 2160, C1428EHA, \\ Buenos Aires, Argentina \\ ${ }^{4}$ Consejo Nacional de Investigaciones Científicas y Técnicas, Centro Austral de Investigaciones Científicas, CC 92, \\ V9410BFD Ushuaia, Tierra del Fuego, Argentina
}

\begin{abstract}
Recent records of lithodid crabs in deeper waters off the Antarctic continental slope raised the question of the return of crabs to Antarctic waters, following their extinction in the lower Miocene $\sim 15$ million years ago. Antarctic cooling may be responsible for the impoverishment of the marine high Antarctic decapod fauna, presently comprising only five benthic shrimp species. Effects of polar conditions on marine life, including lowered metabolic rates and short seasonal food availability, are discussed as main evolutionary driving forces shaping Antarctic diversity. In particular, planktotrophic larval stages should be vulnerable to the mismatch of prolonged development and short periods of food availability, selecting against complex life cycles. We hypothesize that larval lecithotrophy and cold tolerance, as recently observed in Subantarctic lithodids, represent, together with other adaptations in the adults, key features among the life-history adaptations of lithodids, potentially enabling them to conquer polar ecosystems. The return of benthic top predators to high Antarctic waters under conditions of climate change would considerably alter the benthic communities.
\end{abstract}

Key words: Antarctic; biodiversity; climate change; crabs; evolution; marine ecosystems; temperature adaptation.

\section{SOUTHERn OCEAN Decapods in AN Evolutionary CONTEXT}

High latitude decapod crustaceans comprise one of the most unsolved mysteries in marine biodiversity research, with $\sim 120$ benthic shrimp and crab species in the Subantarctic, compared with an extremely impoverished high Antarctic fauna, consisting of only five benthic shrimp representatives on the continental shelf of the Weddell Sea (Arntz and Gorny 1991, Gorny 1999; for zoogeographic classification see, Hedgpeth 1969). At the Late Cretaceous-Early Cenozoic boundary, the Austral Province showed a temperate climate, which was favorable for decapods, as evidenced by a rich fossil record (Feldmann and Zinsmeister 1984 Forster et al. 1987, Feldmann et al. 1997). Faunal impoverishment ending with the probable extinction of crabs $\sim 15$ million years ago is discussed as a result of various processes involved, the principal factor being Antarctic cooling. This process started as early as $\sim 35$ million years ago as a consequence of continental drift (Clarke 1990, 1993, Crame 1999), and affected in particular decapod diversity.

Cold tolerance requires, in the first place, an adjustment of the functional capacity of oxygen supply

Manuscript received 6 April 2004; revised 20 July 2004; accepted 11 August 2004. Corresponding Editor: P. T. Raimondi.

${ }^{5}$ E-mail: sthatje@awi-bremerhaven.de mechanisms such as ventilation and circulation (for discussion see Pörtner 2002, Clarke 2003). In brachyuran crabs, this adjustment is hampered by a special sensitivity to $\left[\mathrm{Mg}^{2+}\right]$, combined with a poor ability to regulate $\left[\mathrm{Mg}^{2+}\right]$ levels in the haemolymph $\left[\mathrm{Mg}^{2+}\right]_{\mathrm{HL}}$ below those in the water. Consequently, their scope for aerobic activity is reduced so that they may be narcotized by a combination of temperatures below $<0^{\circ} \mathrm{C}$ and high $\left(\left[\mathrm{Mg}^{2+}\right]_{\mathrm{HL}}\right)$ levels (Frederich et al. 2001). Such physiological constraints in crab species affect all processes demanding aerobic energy, including their brooding behavior. This makes crabs under cold conditions less competitive as compared to other crustaceans, which are able to down-regulate $\left[\mathrm{Mg}^{2+}\right]_{\mathrm{HL}}$, e.g., shrimps, isopods, and amphipods. Differential capabilities of $\left[\mathrm{Mg}^{2+}\right]_{\mathrm{HL}}$ regulation in crab vs. shrimp species may thus be responsible for the comparatively late worldwide radiation of brachyurans, which required warmer Cretaceous temperatures (Schram 1982). Given that most other decapod taxa are strong $\left[\mathrm{Mg}^{2+}\right]_{\mathrm{HL}}$ regulators at low $\left[\mathrm{Mg}^{2+}\right]_{\mathrm{HL}}$, it is likely that ancestral brachyurans also had high $\left[\mathrm{Mg}^{2+}\right]_{\mathrm{HL}}$ levels (Frederich et al. 2001). However, during the radiation of brachyuran crabs in the Cretaceous, the water temperature was $>0{ }^{\circ} \mathrm{C}$ worldwide, with a minimum polar temperature of $\sim 0^{\circ} \mathrm{C}$ (Barron 1992), which may explain the scarcity of improved $\left[\mathrm{Mg}^{2+}\right]_{\mathrm{HL}}$ regulation capacities in crabs.

This theory, however, does not coincide with the observation of poor magnesium regulation capabilities 

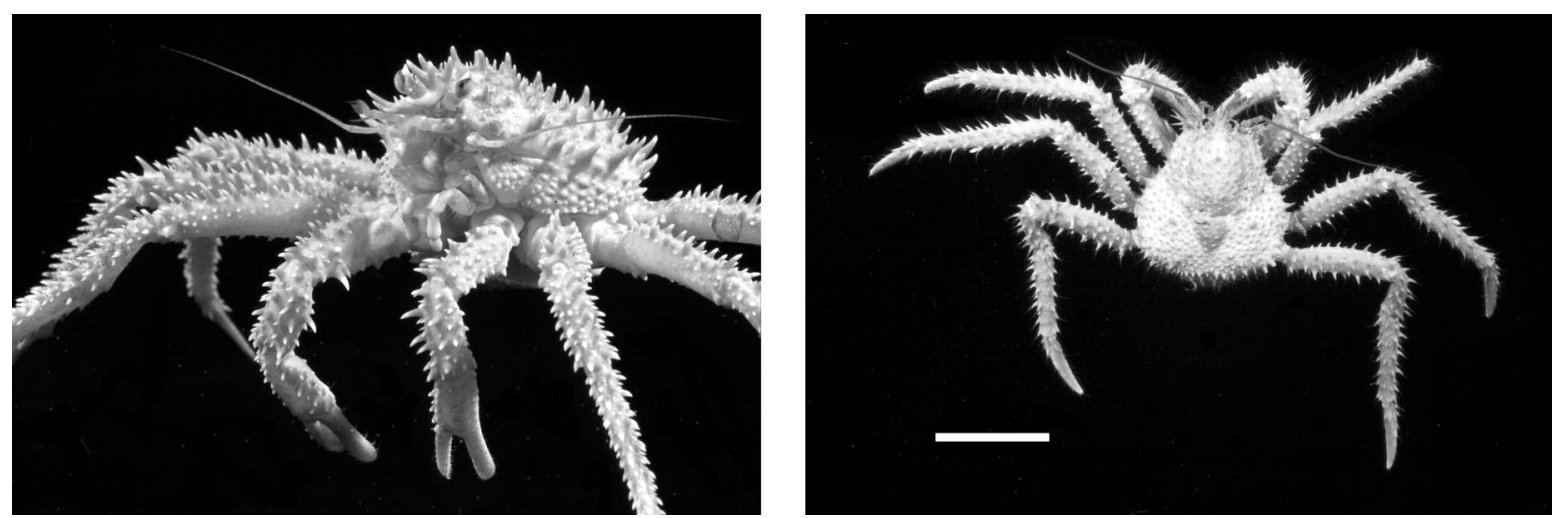

Plate. 1. (Left) Lithodes confundens from the southwestern Atlantic Ocean. Lithodid crabs are considered benthic top predators. Their return to the high Antarctic continental shelves would certainly reshape benthic communities, which have evolved unaffected by crabs during the last $\sim 15$ million years. (Right) An unknown stone crab (Paralomis sp.) from the Spiess seamount near Bouvet Island $\left(\sim 54^{\circ} \mathrm{S}, 03^{\circ} \mathrm{W}\right)$ in the Southern Ocean. The specimen was trawled using an Aggasiz trawl during the German FS "Polarstern" cruise ANT XXI/2 in January 2004 (scale bar = $5 \mathrm{~cm}$ ). Photo credit: Martin Rauscher.

in lithodid crabs (Anomura), which occur with high species diversity in subpolar regions (Zaklan 2002). This taxon represents probably one of the youngest decapod families. The Lithodidae or king crabs evolved 15-23 million years ago (Cunningham et al. 1992, Feldmann 1998; see Plate 1) when the world climate, especially in the Southern Hemisphere, underwent a considerable cooling process eventually resulting in the present conditions.

The complexity of factors involved in decapod extinction also included glaciation events of the Antarctic continental shelf, which may have affected especially brachyuran crab species with a limited bathymetric distribution range. Eurybathic species with a refuge in deeper waters, such as most caridean shrimps of the Southern Ocean, were able to recolonize the shelf, and this may explain why Antarctic invertebrates, in general, show a wider bathymetric distribution than invertebrates from other seas (Brey et al. 1996).

The exact geological timing of decapod extinction is still under discussion, since the rich fossil record principally reflects well established decapod communities until $\sim 15$ million years ago, but does not indicate how long these faunistic elements lasted (Feldmann and Zinsmeister 1984, Forster et al. 1987, Feldmann et al. 1997, Crame 1999). In addition, the fossil record is biased toward Seymour Island, and we know next to nothing about the deep, offshore palaeontological record of the Antarctic. There is, e.g., only one fossil record of deep-water lithodid crabs known from the middle Miocene ( 15 Ma ago, Feldmann 1998). PostEocene diversity patterns are difficult to evaluate, but the relatively scant yet existing fossil decapod record from younger periods (see Feldmann et al. 2003) indicates that at least some species may have survived in refuges on the Antarctic continental slope, which may have remained uncovered during glacial maxima (Feldmann and Crame 1998) or they showed a eury- bathic distribution and survived due to better cold adaptation. The complete extinction process, therefore, was certainly gradual, and the ecological processes involved, for instance competition with other crustaceans such as the brooding isopods and amphipods, which flourished in terms of diversity as a consequence of decapod extinction, are still far from being understood. The observation of an undamaged and well-preserved asteroid and ophiuroid fossil record without indication of regenerated arms from Seymour Island suggests scarcity or a lack of benthos crushers already in the Eocene (Blake and Zinsmeister 1988, Aronson and Blake 1997, 2001).

Recently, large populations of extant king crabs have been discovered in deep waters off the continental shelf in the high Antarctic Bellingshausen Sea at temperatures $>1{ }^{\circ} \mathrm{C}$ (Klages et al. 1995, Arana and Retamal 1999: Fig. 1), reopening the debate about the return of anomuran crabs to Antarctic waters. Since polar conditions should in particular select against the sensitive early life-history stages (Thorson 1936), we suggest that special adaptations should occur in larval physiology and ecology to survive in polar environments with cold and seasonally pulsed planktonic food availability. Recent evidence of larval cold tolerance (Anger et al. 2003, 2004) indicates the capability of lithodid larvae to live under such conditions. Furthermore, it shows physiological limits, which explain the lack of lithodids in high Antarctic waters, where the temperature is permanently $<0^{\circ} \mathrm{C}$ (Arntz et al. 1992), in accordance with the $\mathrm{Mg}^{2+}$ limitation hypothesis (Frederich et al. 2001).

\section{Cold Adaptation vs. Extinction}

Although early life-history data from lithodid species occurring in Antarctic waters are missing so far due mainly to logistic constraints, it appears obvious that lithodid crabs from higher southern latitudes must 

(1) Paralomis anamerae
(9) Lithodes confundens
2 P. spectabilis
(10) L. santolla
(3) P. granulosa
L. murrayi
$\square$ P. formosa
(5) P. spinosissima
(12) L. turkayi
$\triangle 1$ P. birsteini
(13) L. sp. undet. 1
(7) P. tuberipes
(4) L. sp. undet. 2
(8) Neolithodes diomedeae
(15) P. sp. undet. 1

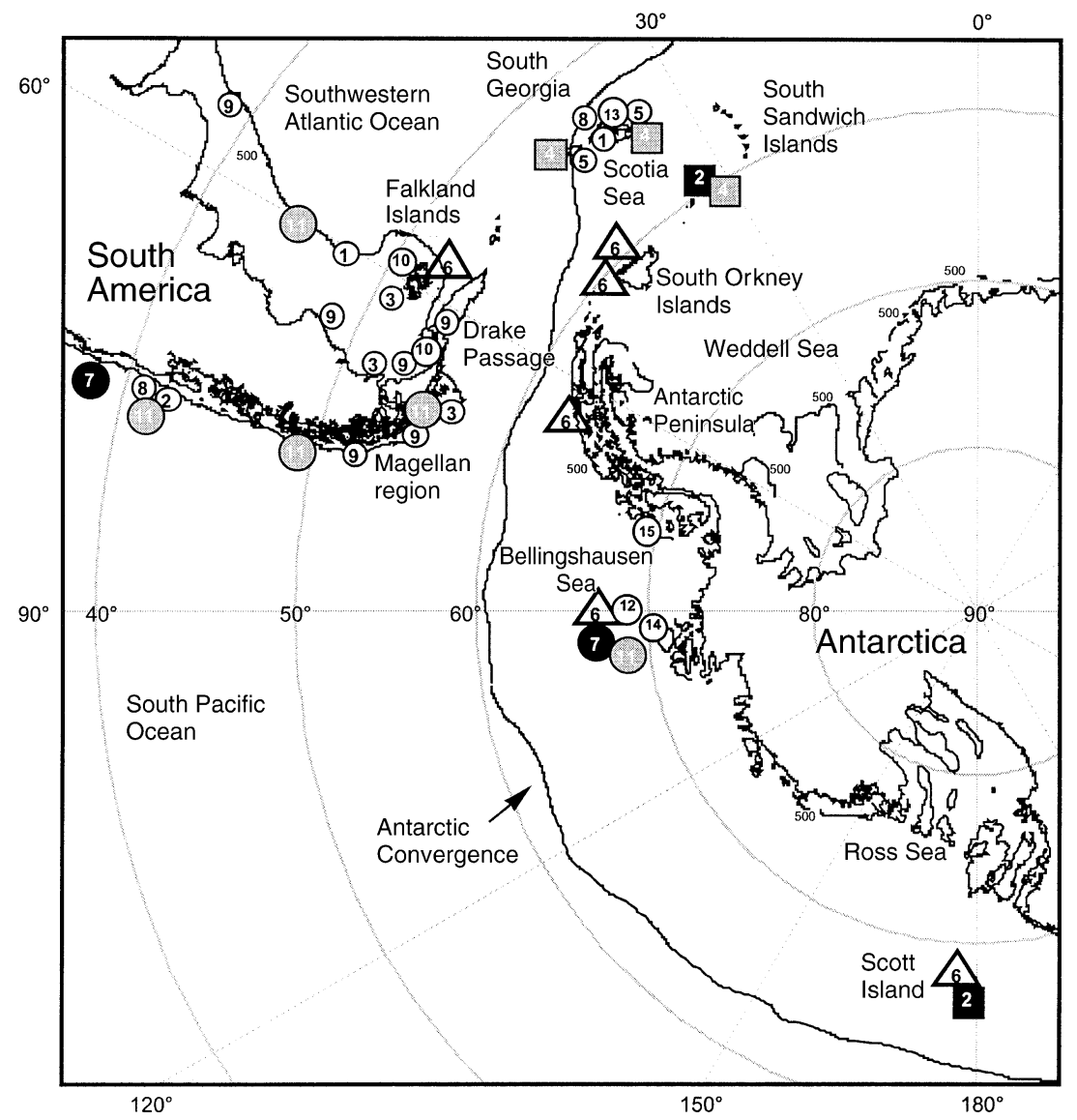

FIG. 1. Occurrence of lithodid crabs in the Southern Ocean, not including records from Crozet and Kerguelen Islands and from waters off New Zealand (see Macpherson 2004). Species occurring across the circum-Antarctic deep sea are highlighted with symbols. Data are from Purves et al. (2003), Thatje and Arntz (2004), and references therein.

have adapted their life history to physiological constraints in the cold. From recent observations in Subantarctic species we may expect traits that minimize the need for activity in both adults and larvae, e.g., prolonged brooding periods of up to about two years (see Lovrich and Vinuesa 1999), extended hatching rhythms of up to several months per brood, and lecithotrophic larval development (see Kattner et al., 2003, Thatje et al. 2003a). Food-independent larval development provides independence from the polar mismatch of distinctly seasonal food availability and prolonged larval development at low temperatures. Furthermore, metabolism should be minimized during the extended, and food-independent, larval develop- ment (up to four months in species from the Magellan region; Anger et al. 2003, 2004, Calcagno et al. 2003). Since harsh environmental conditions prevailing in polar seas should, in the first place, affect the particularly sensitive early life-history stages (Thorson 1936), we hypothesize that the larval stages of lithodids must show key adaptations to these conditions. This becomes particularly evident when we consider the rarity of endotrophic and abbreviated larval developments in brachyuran crabs (Thatje et al. 2003b). Larvae of the false southern king crab, Paralomis granulosa (see Plate 1), seem to have a better cold tolerance than those of the true southern king crab, Lithodes santolla, which allows for completing larval developments at $\sim 1^{\circ} \mathrm{C}$ 


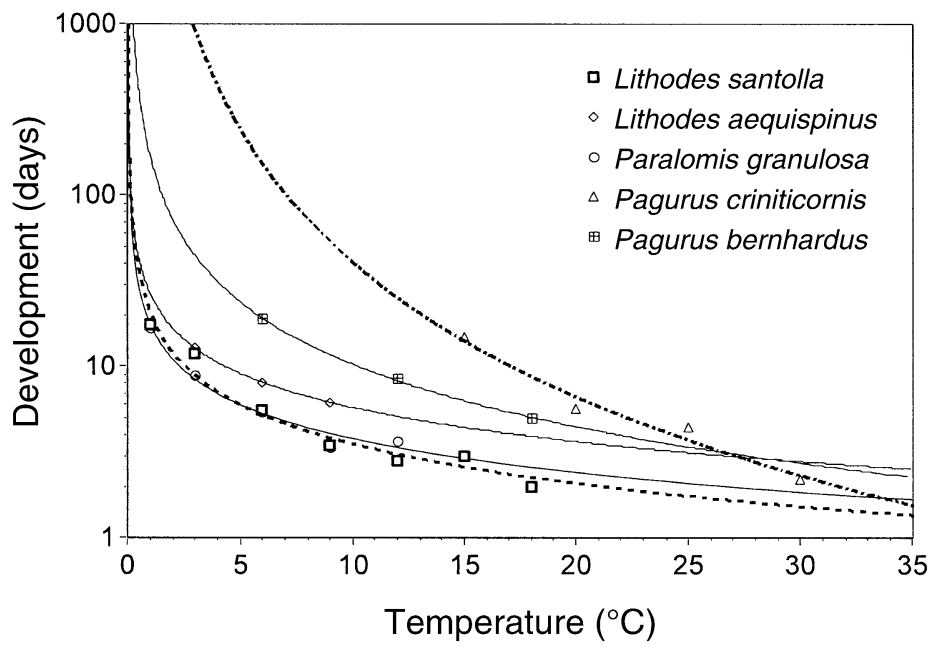

FIG. 2. Extrapolation of temperature-dependent shifts in zoea I development duration (log scale) in species of Lithodidae and Paguridae. Plot symbols show experimental temperatures, roughly representing the natural temperature tolerance window of the zoea I instar. The Lithodidae represent species from high latitudes of both hemispheres, whereas the closely related Paguridae, Pagurus bernhardus and P. criniticornis, represent boreal and tropical species, respectively. Data are from Paul and Paul (1999) for L. aequispinus, Anger et al. (2003) for Paralomis granulosa, Anger et al. (2004) for $L$. santolla, Dawirs (1979) for P. bernhardus, and Blaszkowski and Moreira (1986) for P. criniticornis.
(Anger et al. 2003). This coincides with biogeographic patterns, and consequently, is an indication for speciesspecific latitudinal temperature adaptation (Anger et al. 2003, 2004; for discussion see Clarke 2003).

The outstanding capability of lithodid crabs with an endotrophic mode of larval development to cope with temperatures that are typical of deep-sea and high latitudinal environments is conspicuous when we compare it to the phylogenetically closely related hermit crabs from lower and tropical latitudes. While lithodids show a physiological threshold for successful larval development only at $\sim 1^{\circ} \mathrm{C}$ (Fig. 2), hermit crabs, which are not represented in the polar realm, show much higher temperature limits. An extrapolation of developmental duration through the zoea I at high latitudes would exceed theoretical periods of several years (Fig. 2). However, lithodids from the Antarctic Bellingshausen Sea may not show much better larval temperature adaptations than their congeners from the Subantarctic (cf. Fig. 2), maybe explaining why lithodids are apparently absent from the Weddell Sea, where temperatures permanently drop $<0^{\circ} \mathrm{C}$ (compare Arntz et al. 1992 with Klages et al. 1995). In conclusion, it needs to be emphasized that lithodid diversity and performance in the cold is high, but does not reach below the $\mathrm{Mg}^{2+}$ limits of $0^{\circ} \mathrm{C}$. Hypometabolism and optimization of all life cycle stages to low temperature may be the physiological key to the success of this group in polar seas.

\section{The DeeP-Sea Connection}

Although larval lecithotrophy seems to be a common pattern in lithodid species from high latitudes of both hemispheres (e.g., Anger 1996, Shirley and Zhou 1997, Calcagno et al. 2003, Kattner et al. 2003, Lovrich et al. 2003), the apparent lack of at least partially planktotrophic larval developments in lithodids from the Southern Ocean and adjacent waters may be due to their presumable origin from deep-sea ancestors, since environmental conditions of polar and deep-sea environments require very similar life-history adaptations to cold and food limitation (Thiel et al. 1996). It has been suggested that lithodid crabs evolved in shallow waters of the northern Pacific and have radiated and colonized the Southern Ocean through the Pacific deep sea (Makarov 1962, Zaklan 2002). Since the cold-tolerant lithodid species are not able to cope with tropical warm-water conditions, faunal exchange through the deep sea is assumed as the only possibility connecting the northern and southern hemisphere lithodid populations. In contrast, it has been suggested that lithodids at high latitudes in the northern hemisphere radiated widely through shallower and coastal waters, which may explain the development of planktotrophic developments in some representatives (Makarov 1962, Paul et al. 1989, Zaklan 2002).

We hypothesize that the recolonization of the Antarctic by lithodid crabs should occur via the deep sea, facilitated by similar evolutionary selection pressures in both cold regions and deep-sea environments, namely scarcity of food in combination with low temperatures. A colonization of the Antarctic may also be possible via the shallows of the Subantarctic islands (Dell 1972), as suggested by patterns of distribution of lithodid species, along the islands of the Scotia Arc (Fig. 1). However, active migration via the deep sea appears to be more likely, since lecithotrophic larvae are demersal and show a low potential of dispersal (Thatje et al. 2003a). The demersal behavior of rather immobile lecithotrophic larvae makes it likely that the larvae of deep-sea lithodids develop in the bathyal and are not exported into the euphotic zone of shallow waters, implying that they must be able to cope with the highpressure regime of the deep sea. Lithodid species have been found in a range from the shallow sublittoral to the deep sea, and many species must be considered bathyal (Zaklan 2002: Fig. 3). Despite only a few studies on Antarctic deep-sea environments available, even 


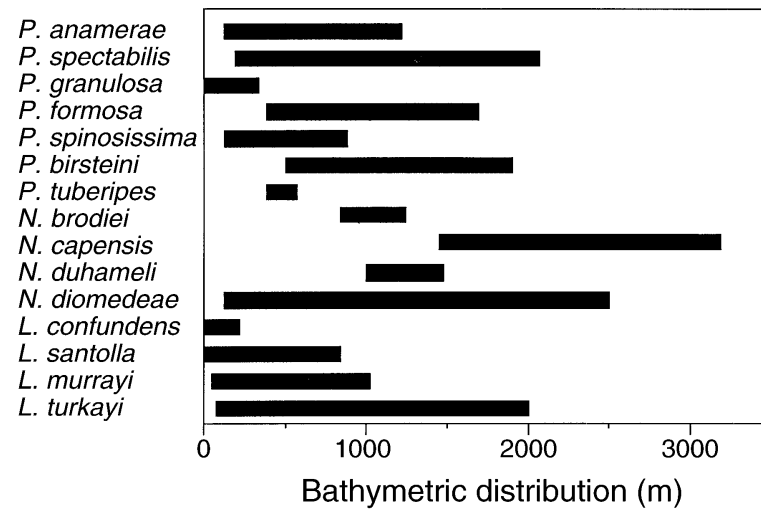

FIG. 3. Bathymetric distribution of lithodid crabs in the Southern Ocean (antarctic and subantarctic). Continuous distribution between end point dots is assumed. Abbreviations of genera are Neolithodes (N.), Lithodes (L.), and Paralomis $(P$.$) . Data are from Purves et al. (2003), Thatje and Arntz$ (2004) and references therein, and Macpherson (2004) and references therein.

our scarce knowledge of lithodid bathymetric distribution patterns in the Southern Ocean already indicates that some lithodid species found in both the Antarctic and Subantarctic marine realm, should have the capability to cross the circum-Antarctic deep sea (compare Figs. 1, 3), with, on average, $>3000 \mathrm{~m}$ depth.

Although, from an evolutionary point of view, lithodids invaded the deeper waters off the Antarctic recently (Cunningham et al. 1992), it remains uncertain whether this process is continuing. Most lithodids collected with bottom trawls or baited traps have been recorded only during the last years (see Thatje and Arntz 2004), although such gear (in particular bottom trawls and video imaging) has been used frequently in the high Antarctic Weddell and Lazarev Seas throughout the last two decades (Arntz et al. 1994, Thatje and Arntz 2004). The question of recolonization remains thus as an exciting challenge and subject to speculation. Nevertheless, it is certain that insufficient cold adaptation in lithodid larvae (Fig. 2) to temperatures typical of the high Antarctic Weddell and Ross Seas $\left(\sim 0^{\circ} \mathrm{C}\right.$ to $-1.9^{\circ} \mathrm{C}$, Arntz et al. 1992) may explain why these crabs have not yet invaded the high Antarctic continental shelves (Gorny 1999). The formation of cold bottom water in the high Antarctic Weddell and Ross Seas (compared to higher bottom water temperatures, e.g., in the Bellingshausen Sea; Klages et al. 1995) may also explain the lack of lithodid records in the southern Weddell Sea and Lazarev Sea. Lithodids occur frequently along the bordering Scotia Arc islands (Fig. 1) and a species of Paralomis was found near Bouvet Island (S. Thatje, unpublished record; see Plate 1). Considering that a continued climate shift will lead to more favorable temperature conditions for crabs in the high Antarctic marine environment, the return of shellcrushing benthic top predators, which are presently excluded from the ecosystem (Arntz et al. 1994, Dayton et al. 1994), will considerably reshape and alter high latitudinal benthos communities. We suggest that this process has already started. In the present high Antarctic system, amphipods and isopods occupy part of the ecological niche of crabs (Brandt 1991), and asteroids are considered further benthic top predators (Arntz et al. 1994, Dayton et al. 1994, Aronson and Blake 2001). Echinoderms, in particular asteroids, as well as peracarid crustaceans constitute an important part of prey for lithodids (Jewett and Feder 1982, Comoglio and Amin 1999), implying a direct impact of lithodids on the Antarctic food web, which may reshape the benthic ecosystem.

Despite an invasion of adult lithodid crabs most likely occurring across the deep sea, scant records of brachyuran and anomuran crab larvae near the Antarctic Peninsula, which have been suggested to cross the Polar Front by means of eddies (Thatje and Fuentes 2003, Glorioso et al. in press), suggest that there may be a colonization pressure also from decapod taxa which, under present climate conditions, remain excluded and are not able to settle and establish populations in Antarctic waters. Crossing the Antarctic Circumpolar Current, which has always been considered as the main oceanographic barrier isolating the Antarctic biota from surrounding seas (Clarke 1990, Crame 1999), may thus be another future colonization mechanism in the Antarctic marine realm. Another phenomenon, the recent record of two adult specimens of the spider crab Hyas araneus, native to boreal and subarctic waters, off the Antarctic Peninsula (Tavares and De Melo 2004), has been suggested to be the first invasive benthic invertebrate in Antarctic waters. According to the authors this species may have been introduced by means of ballast water or by biofouling organisms on ship hulls, raising the question, however, how these crabs (larvae or adults) managed to survive the high temperatures in the tropics (for temperature thresholds see Anger 1983). In summary, these examples suggest that we have to remain flexible in our perspectives on evolutionary time scales in the development of the Antarctic marine fauna in response to climate shift.

Combined ecological and physiological studies on marine invertebrates will help substantially to improve our understanding of past, present, and future changes in the marine biota under conditions of climate change. In the case of the Decapoda, future research should also focus on phylogenetic implications applying molecular techniques to elucidate the presumable but controversially discussed relationships between the Lithodidae and the Paguridae (for discussion, see Cunningham et al. 1992, McLaughlin and Lemaitre 2000), and scrutinize whether $\mathrm{Mg}^{2+}$ regulation capacities are phylogenetically significant. The relationships among $\mathrm{Mg}^{2+}$ concentration, oxygen utilization, and behavioral changes in both adults and larvae may help in understanding radiation processes on geological time scales, 
as in the Brachyura, which flourished during the relatively warm Cretaceous period.

\section{ACKNOWLEDGMENTS}

This work benefitted from discussions with Andrew Clarke (British Antarctic Survey), Eduardo Olivero (CADIC, Ushuaia), Alistair Crame (British Antarctic Survey), Katrin Linse (British Antarctic Survey), and Christoph Held (RuhrUniversity Bochum). We are indebted to the International Bureau of the German Ministry of Research (BMBF, project number Arg 99/002) and the Argentine Secretaría Nacional para la Ciencia, Tecnología e Inovación Productiva (SECyT) for continuous financial support of this bilateral cooperation during the last years. We would like to thank two anonymous reviewers for their valuable comments on an earlier draft of this work

\section{Literature Cited}

Anger, K. 1983. Temperature and the larval development of Hyas araneus L. (Decapoda: Majidae); extrapolation of laboratory data to field conditions. Journal of Experimental Marine Biology and Ecology 69:203-215.

Anger, K. 1996. Physiological and biochemical changes during lecithotrophic larval development and early juvenile growth in the northern stone crab, Lithodes maja (Decapoda: Anomura). Marine Biology 126:283-296.

Anger, K., G. A. Lovrich, S. Thatje, and J. A. Calcagno. 2004. Larval and early juvenile development of Lithodes santolla (Molina, 1782) (Decapoda: Anomura: Lithodidae) reared at different temperatures in the laboratory. Journal of Experimental Marine Biology and Ecology 306:207-230.

Anger, K., S. Thatje, G. A. Lovrich, and J. A. Calcagno. 2003. Larval and early juvenile development of Paralomis granulosa reared at different temperatures: tolerance of cold and food limitation in a lithodid crab from high latitudes. Marine Ecology Progress Series 253:243-251.

Arana, P. M., and M. A. Retamal. 1999. Nueva distribución de Paralomis birsteini Macpherson 1988 en aguas antárticas (Anomura, Lithodidae, Lithodinae). Investigaciones Marinas (Valparaíso) 27:101-110.

Arntz, W. E., T. Brey, and V. A. Gallardo. 1994. Antarctic zoobenthos. Oceanography and Marine Biology Annual Review 32:241-304.

Arntz, W. E., T. Brey, D. Gerdes, M. Gorny, J. Gutt, S. Hain, and M. Klages. 1992. Patterns of life history and population dynamics of benthic invertebrates under the high Antarctic conditions of the Weddell Sea. Pages 221-230 in G. Colombo, I. Ferrari, V. U. Ceccherelli, and R. Rossi, editors. Marine eutrophication and population dynamics. Proceedings of the 25th European Marine Biology Symposium. Olsen and Olsen, Fredensborg, Denmark.

Arntz, W. E., and M. Gorny. 1991. Shrimp (Decapoda, Natantia) occurrence and distribution in the eastern Weddell Sea, Antarctica. Polar Biology 11:169-177.

Aronson, R. B., and D. B. Blake. 1997. Global climate change and the paleoecology of echinoderm populations at Seymour Island, Antarctica. Antarctic Journal of the United States 32:20-22.

Aronson, R. B., and D. B. Blake. 2001. Global climate change and the origin of modern benthic communities in Antarctica. American Zoologist 41:27-39.

Barron, E. J. 1992. Paleoclimatology. Pages 485-505 in G. Brown, C. Hawkesworth, and C. Wolson, editors. Understanding the Earth. Cambridge University Press, Cambridge, UK.

Blake, D. B., and W. J. Zinsmeister. 1988. Eocene asteroids (Echinodermata) from Seymour Island, Antarctic Peninsula. In R. M. Feldmann and M. O. Woodburne, editors. Geology and paleontology of Seymour Island, Antarctic
Peninsula. Geological Society of America, Memoirs 169 489-498.

Blaszkowski, C., and G. S. Moreira. 1986. Combined effects of temperature and salinity on the survival and duration of larval stages of Pagurus criniticornis (Dana) (Crustacea, Paguridae). Journal of Experimental Marine Biology and Ecology 103:77-86.

Brandt, A. 1991. Origin of Antarctic Isopoda (Crustacea, Malacostraca). Marine Biology 113:415-423.

Brey, T., C. Dahm, M. Gorny, M. Klages, M. Stiller, and W. E. Arntz. 1996. Do Antarctic benthic invertebrates show an extended level of eurybathy? Antarctic Science 8:3-6.

Calcagno, J. A., S. Thatje, K. Anger, G. A. Lovrich, and A. Kaffenberger. 2003. Changes in biomass and chemical composition during lecithotrophic larval development of the Southern stone crab, Paralomis granulosa (Jacquinot). Marine Ecology Progress Series 257:189-196.

Clarke, A. 1990. Temperature and evolution: southern Ocean cooling and the Antarctic marine fauna. Pages 9-22 in K. R. Kerry and G. Hempel, editors. Antarctic ecosystems. Ecological change and conservation. Springer-Verlag Berlin, Heidelberg, Germany.

Clarke, A. 1993. Temperature and extinction in the sea: a physiologist's view. Paleobiology 19:499-518.

Clarke, A. 2003. Costs and consequences of evolutionary temperature adaptation. Trends in Ecology and Evolution 18:573-581.

Comoglio, L. I., and O. A. Amin. 1999. Feeding habits of the false southern king crab Paralomis granulosa (Lithodidae) in the Beagle Channel, Tierra del Fuego, Argentina. Scientia Marina 63(Supplement 1):361-366.

Crame, J. A. 1999. An evolutionary perspective on marine faunal connections between southernmost South America and Antarctica. Scientia Marina 63(Supplement 1):1-14.

Cunningham, C. W., N. W. Blackstone, and L. W. Buss. 1992. Evolution of king crabs from hermit crab ancestors. Nature 355:539-542.

Dawirs, R. R. 1979. Effects of temperature and salinity on larval development of Pagurus bernhardus (Decapoda, Paguridae). Marine Ecology Progress Series 1:323-329.

Dayton, P. K., B. J. Mordida, and F. Bacon. 1994. Polar marine communities. American Zoologist 34:90-99.

Dell, R. K. 1972. Antarctic benthos. Advances in Marine Science 10:1-216.

Feldmann, R. M. 1998. Paralomis debodeorum, a new species of decapod crustacean from the Miocene of New Zealand: first notice of the Lithodidae in the fossil record. New Zealand Journal of Geology and Geophysics 41:35-38.

Feldmann, R. M., M. Aguirre-Urreta, L. Chirino-Halvez, and S. Casadío. 1997. Palaeobiogeography of Cretaceous and Tertiary decapod crustaceans from southern South America: the link with Antarctica. Pages 1007-1016 in C. A. Ricci, editor. The Antarctic region: geological evolution and processess. Terra Antartica, Siena, Italy.

Feldmann, R. M., and J. A. Crame. 1998. The significance of a new nephropid lobster from the Miocene of Antarctica. Palaeontology 41:807-814.

Feldmann, R. M., C. W. Schweitzer, and A. Marenssi. 2003. Decapod crustaceans from the Eocene La Meseta Formation, Seymour Island, Antarctica: a model for preservation of decapods. Journal of the Geological Society London 160: 151-160.

Feldmann, R. M., and W. J. Zinsmeister. 1984. New fossil crabs (Decapoda: Brachyura) from the La Meseta Formation (Eocene) of Antarctica: paleogeographic and biogeographic implications. Journal of Paleontology 58:10461061.

Forster, R., A. Gazdzicki, and R. Wrona. 1987. Homolodromiid crabs from the Cape Melville formation (Lower Miocene) of King George Island, West Antarctica. Palaeon- 
tological Research of the Polish Antarctic Expedition 49: 147-161.

Frederich, M., F. J. Sartoris, and H. O. Pörtner. 2001. Distribution patterns of decapod crustaceans in polar areas: a result of magnesium regulation? Polar Biology 24:719723.

Glorioso, P. D., A. R. Piola, and R. R. Leben. In press. Mesoscale eddies in the Subantarctic Front-Southwest Atlantic. Scientia Marina (Supplement).

Gorny, M. 1999. On the biogeography and ecology of the Southern Ocean decapod fauna. Scientia Marina 63(Supplement 1):367-382.

Hedgpeth, J. W. 1969. Introduction to Antarctic zoogeography. American Geographical Society Antarctic Map Folio Series 11:1-41.

Jewett, S. C., and H. M. Feder. 1982. Food and feeding habits of the king crab Paralithodes camtschatica near Kodiak Island, Alaska. Marine Biology 66:243-250.

Kattner, G., M. Graeve, J. A. Calcagno, G. A. Lovrich, S. Thatje, and K. Anger. 2003. Lipid, fatty acid and protein utilization during lecithotrophic larval development of Lithodes santolla (Molina) and Paralomis granulosa (Jacquinot). Journal of Experimental Marine Biology and Ecology 292:61-74.

Klages, M., J. Gutt, A. Starmans, and T. Bruns. 1995. Stone crabs close to the Antarctic continent: Lithodes murrayi Henderson, 1888 (Crustacea; Decapoda; Anomura) off Peter I Island $\left(68^{\circ} 51^{\prime} \mathrm{S}, 90^{\circ} 51^{\prime} \mathrm{W}\right)$. Polar Biology 15:73-75.

Lovrich, G. A., S. Thatje, J. A. Calcagno, K. Anger, and A. Kaffenberger. 2003. Changes in biomass and chemical composition during lecithotrophic larval development of the Southern king crab, Lithodes santolla (Molina). Journal of Experimental Marine Biology and Ecology 288:65-79.

Lovrich, G. A., and J. H. Vinuesa. 1999. Reproductive potential of the lithodids Lithodes santolla and Paralomis granulosa (Anomura, Decapoda) in the Beagle Channel, Argentina. Scientia Marina 63(Supplement 1):355-360.

Macpherson, E. 2004. A new species and new records of lithodid crabs (Crustacea: Decapoda: Lithodidae) from the Crozet and Kerguelen Islands area (Subantarctica). Polar Biology 27:418-422.

Makarov, V. V. 1962. Fauna of U.S.S.R. (Crustacea). Pages 1-283 in A. A. Shtakelberg, editor. Israel Programme for Scientific Translation. Jerusalem, Israel.

McLaughlin, P. A., and R. Lemaitre. 2000. Aspects of evolution in the anomuran superfamily Paguroidea: one larval perspective. Invertebrate Reproduction and Development 38: $159-169$.

Paul, A. J., and J. M. Paul. 1999. Development of larvae of the golden king crab Lithodes aequispinus (Anomura: Lithodidae) reared at different temperatures. Journal of Crustacean Biology 19:42-45.

Paul, A. J., J. M. Paul, and K. O. Coyle. 1989. Energy sources for first-feeding zoeae of king crab Paralithodes camtscha- tica (Tilesius) (Decapoda, Lithodidae). Journal of Experimental Marine Biology and Ecology 130:55-69.

Pörtner, H. O. 2002. Climate variations and the physiological basis of temperature dependent biogeography: systemic to molecular hierarchy of thermal tolerance in animals. Comparative Biochemistry and Physiology 132A:739-761.

Purves, M. G., D. J. Agnew, G. Moreno, C. Yau, and G. Pilling. 2003. Distribution, demography, and discard mortality of crabs caught as bycatch in an experimental pot fishery for toothfish (Dissostichus eleginoides) in the South Atlantic. Fishery Bulletin 101:874-888.

Schram, F. R. 1982. The fossil record and evolution of Crustacea. Pages 93-147 in L. G. Abele, editor. The biology of Crustacea. Volume 1. Academic Press, New York, New York, USA.

Shirley, T. C., and S. Zhou. 1997. Lecithotrophic development of the golden king crab Lithodes aequispinus (Anomura: Lithodidae). Journal of Crustacean Biology 17:207216.

Tavares, M., and G. A. S. De Melo. 2004. Discovery of the first known benthic invasive species in the Southern Ocean: the North Atlantic spider crab Hyas araneus found in the Antarctic Peninsula. Antarctic Science 16:129-131.

Thatje, S., and W. E. Arntz. 2004. Antarctic reptant decapods: more than a myth? Polar Biology 27:195-201.

Thatje, S., J. A. Calcagno, G. A. Lovrich, F. J. Sartoris, and K. Anger. 2003a. Extended hatching periods in the Subantarctic lithodid crabs Lithodes santolla and Paralomis granulosa (Crustacea: Decapoda). Helgoland Marine Research 57:110-113.

Thatje, S., and V. Fuentes. 2003. First record of anomuran and brachyuran larvae (Crustacea: Decapoda) from Antarctic waters. Polar Biology 26:279-282.

Thatje, S., S. Schnack-Schiel, and W. E. Arntz. 2003b. Developmental trade-offs in Subantarctic meroplankton communities and the enigma of low decapod diversity in high southern latitudes. Marine Ecology Progress Series 260: 195-207.

Thiel, H., H. O. Pörtner, and W. E. Arntz. 1996. Marine life at low temperatures - a comparison of polar and deep-sea characteristics. In F. Uiblein, J. Ott, and M. Stachowitsch, editors. Deep-sea and extreme shallow-water habitats: affinities and adaptations. Biosystematics and Ecology Series 11:183-219.

Thorson, G. 1936. The larval development, growth and metabolism of Arctic marine bottom invertebrates compared with those of other seas. Meddelingen om Grönland 100: $1-155$.

Zaklan, S. D. 2002. Review of the family Lithodidae (Crustacea: Anomura: Paguroidea): distribution, biology, and fisheries. Pages 751-845 in A. J. Paul, E. G. Dawe, R. Elner, G. S. Jamieson, G. H. Kruse, R. S. Otto, B. SainteMarie, T. C. Shirley, and D. Woodby, editors. Crabs in cold water regions: biology, management, and economics. University of Alaska Sea Grant College Program AK-SG-0201, Fairbanks, Alaska, USA. 